\title{
Hubungan Karakter AKTivitas Dan Karakter BERLOKASI PKL DI KoTA SURAKARTA
}

\author{
MURTANTI JANI R, S.T., M.T. \\ PROGRAM STUDi PERENCANAAN WILAYAH DAN KoTA, \\ FAKULTAS TEKNIK \\ Universitas SEBElas MARET, SURAKARTA \\ RINA WULANDARI, S.T. \\ PIPW LPPM \\ UniVERsitas SEBElas MARET, SURAKARTA
}

\begin{abstract}
PKL sebagai bagian dari sektor informal mempunyai karakteristik aktivitas berbeda dengan pedagang sektor formal. Selain itu, PKL juga memiliki karaktersitik khusus dalam memilih lokasi berdagang. Dengan alasan-alasan tertentu, PKL memilih lokasi yang tepat untuk menjaga keberlangsungan usaha dagang/pelayanan mereka yang sesuai dengan persepsi yang dimiliki. Karakteristik berlokasi PKL memiliki hubungan dengan karakteristik aktivitasnya, antara lain: luas tempat berdagang, jenis sarana dagang, lama berjualan dalam sehari, lama transaksi, jumlah konsumen, dan asal konsumen. Sedangkan karakteristik berlokasinya terdiri dari 4 hal yaitu jenis aktivitas yang didekati, pola pengelompokkan usaha, sifat layanan, dan kedekatan dengan konsumen. Tujuan dari penelitian ini adalah untuk mengetahui hubungan antara karakter berlokasi PKL dengan karakter aktivitasnya. Untuk mengetahui hubungan tersebut dilakukan analisi crosstab. Berdasarkan hasil analisis tersebut, ditemukan bahwa aktivitas yang dilakukan PKL akan berpengaruh terhadap keputusan PKL dalam berlokasi. Hal ini terlihat pada hubungan yang terjalin antara jenis aktivitas yang didekati PKL dengan jenis sarana dagang, jumlah konsumen, dan asal konsumen; hubungan antara pola pengelompokkan PKL dengan luas tempat berdagang dan lama transaksi; sifat layanan PKL yang berhubungan dengan jenis sarana dagang, luas tempat berdagang, dan asal konsumen; dan hubungan antara kedekatan dengan konsumen dengan jumlah konsumen.
\end{abstract}

Keywords: karakteristik aktivitas, karakteristik berlokasi, aktivitas utama, sifat pelayanan, pengelompokan usaha, kedekatan dengan konsumen

\section{PENDAHULUAN}

Pelaku sektor informal perkotaan di Indonesia didominasi oleh penduduk yang melakukan urbanisasi dari desa ke kota dengan kondisi ekonomi menengah ke bawah dan hanya memiliki pendidikan, keterampilan, pendidikan, dan kapasitas terbatas untuk masuk dalam sektor formal (Hariyono, 2007). Pertumbuhan sektor informal di perkotaan sulit dikendalikan jumlahnya, termasuk subsektor PKL. Hal ini dapat terjadi karena untuk masuk ke dalam sektor ini tidak membutuhkan persyaratan tertentu. Secara umum, sektor informal berfungsi sebagai "katup pengaman" bagi perekonomian perkotaan dimana mampu membawa masyarakat yang "unemployment" menjadi employment, sehingga pada tahap selanjutnya sektor informal dapat membuka peluang yang sangat besar bagi pelakunya untuk dapat memasuki sektor formal. Di samping itu, sektor informal dapat pula diandalkan untuk menanggulangi masalah kemiskinan di perkotaan. Sektor informal memiliki elastisitas serta ketahanan dimana dapat menampung tenaga kerja yang tidak terserap oleh sektor formal (Rahayu, et al, 2007). Kemampuan sektor informal untuk menutup celah pasar yang tidak terpenuhi oleh 
sektor formal ini, membentuk hubungan simbiosis mutualisme dengan konsumennya,

bagi masyarakat menengah ke bawah (Rahayu, et.al, 2013). Hal ini menunjukan bahwa sektor informal memiliki andil dalam mensubsidi sektor formal (Swasono, 1997).

Fenomena menjamurnya PKL di perkotaan juga terjadi di Kota Surakarta. PKL di Kota Surakarta tumbuh subur hingga tahun 2008. Pada tahun 2008, terbit Perda No. 3 Tahun 2008 tentang Pengelolaan PKL dimana pemerintah berwenang untuk menetapkan, memindahkan dan menghapus lokasi PKL dengan memperhatikan kepentingan sosial, ekonomi, ketertiban dan kebersihan lingkungan di sekitarnya. Strategi penataan PKL di Kota Surakarta dilakukan dengan menggunakan bentuk penataan relokasi dan stabilisasi. Secara fisik, kedua bentuk penataan tersebut telah dapat merubah wajah kota menjadi lebih indah dan teratur. Akan tetapi, hasil penelitian Rahayu, et al (2012 dan 2013) menunjukkan bahwa tujuan penataan PKL belum sepenuhnya berhasil mencapai tujuan pengelolaan secara komprehensif. Banyak PKL yang mengalami penataan relokasi memilih pindah dari lokasi relokasi. Sementara PKL yang ditata dengan cara stabilisasi merasa penghasilannya belum meningkat secara signifikan. Hal ini disebabkan karena pemilihan lokasi relokasi yang tidak mempertimbangkan karakter aktivitas PKL seperti jenis dagangan, kebutuhan beraglomerasi dan kebutuhan utilitas, sifat maupun skala pelayanan. Sedangkan pada penataan stabilisasi, kekurangan utilitas dan fasilitas tertentu yang sesuai dengan karakter aktivitas belum dipenuhi (Rahayu, et. al., 2013). Berdasarkan kondisi diatas, maka peneliti merasa penting untuk mengetahui hubungan yang karakter aktivitas PKL dengan karakter berlokasinya.

\section{METODE PENELITIAN}

Dalam penelitian ini pemahaman secara komprehensif dilakukan terhadap PKL terkait karakteristik aktivitas PKL melandasi bagaimana PKL berlokasi. Penelitian ini merupakan kelanjutan penelitian PKL yang dimana sektor informal mampu menyediakan kebutuhan dengan harga yang terjangkau

juga dilakukan oleh peneliti yang sama sebelumnya, sehingga PKL sebagai obyek penelitian tetap menggunakan klasifikasi jenis dagangan yang sama pula. Di dalam penelitian Rahayu et al (2012, 2013, 2014), PKL diklasifikasikan menjadi:

1) Makanan mentah seperti sayur mayur, buah-buahan, daging, ikan, ayam, bumbubumbu,

2) Makanan siap saji di bawa pulang seperti jus, kripik, gorengan, srabi, pukis, krupuk/karak, dan lainnya,

3) Makanan siap saji dimakan di tempat seperti warung bakmi, warung makan jawa, warung padang, warung makan jawa dan lainnya,

4) Non makanan seperti baju, onderdil, HP, rokok, tanaman hias, dompet, dan lainnya, serta

5) Jasa pelayanan (services) seperti tukang cukur, tambal ban, afdruk foto, tukang jahit/permak, pijat, plat nomor, stempel, service alat elektronik, dan lain-lain.

Pengumpulan data dilakukan dengan pemetaan kantong-kantong PKL berdasarkan jenis dagangannya di Kota Surakarta dan juga penyebaran kuisioner untuk mengetahui karakter berlokasi yang meliputi: jenis aktivitas utama yang didekati, pola pengelompokan, sifat pelayanan dan kedekatan dengan konsumen. Sedangkan data terkait karakter aktivitas PKL yang meliputi: luas tempat berdagang, jenis sarana dagang, lama berjualan dalam sehari, lama transaksi, jumlah konsumen, dan asal konsumen.

Penentuan jumlah sampel dilakukan dengan teknik sampling kuota dimana sampel dipilih berdasarkan kuota yang diinginkan berdasarkan populasi dengan ciri tertentu. Untuk mengetahui hubungan antara karakter berlokasi PKL dengan karakter aktivitasnya akan digunakan teknik analisis cross tab. Teknik analisis ini digunakan untuk menunjukkan distribusi dan pengujian hubungan antara dua variabel yaitu variable karakter lokasi PKL dan karakter aktivitasnya. Melalui hasil uji signifikansi, jika nilai sig $<0,05$ berarti ada hubungan antara karakteristik aktivitas dengan karakteristik lokasi PKL. Sebaliknya, jika nilai sig $>0,05$ berarti tidak ada hubungan 
antara karakteristik aktivitas dengan karakteristik lokasi PKL. Selanjutnya untuk melihat nilai keeratan hubungan yang dibentuk dilakukan dengan menghitung koefisien kontingensi dimana semakin tinggi nilai koefisien kontingensi, maka semakin erat hubungannya.

\section{HASIL DAN PEMBAHASAN}

\section{a. Karakteristik Aktivitas PKL}

Karakteristik aktivitas PKL ditinjau berdasarkan sarana fisik yang berupa luas tempat berdagang, jenis sarana dagang, dan pola pelayanan yang berupa lama berjualan dalam sehari, lama transaksi, jumlah konsumen, dan asal konsumen. Berikut adalah karakter aktivitas PKL di Kota Surakarta:

1) Secara umum, sejumlah 44 persen PKL memilih menggunakan sarana dagang gerobak. Namun, jika dilihat berdasarkan jenis dagangannya, sebagain besar PKL makanan siap saji ditempat lebih memilih menggunakan sarana dagang berupa warung/tenda, sedangkan mayoritas PKL makanan siap saji dibawa pulang menggunakan sarana dagang gerobak dan PKL makanan mentah lebih memilih alas/gelaran sebagai sarana dagangnya.

2) Sejumlah 45 persen PKL di Kota Surakarta memiliki luas tempat berdagang kurang dari $3 \mathrm{~m}^{2}$, sedangkan 42,67 persen sisanya menggunakan luas tempat berdagang 3-6 $\mathrm{m}^{2}$, dan 12 persen PKL memiliki luas berdagang lebih dari $6 \mathrm{~m}^{2}$. Jika ditinjau berdasarkan jenis dagangannya, PKL makanan siap saji ditempat membutuhkan luas tempat bedagang yang cukup besar, hal ini disebabkan kebutuhan aktivitas dari PKL ini untuk mengolah makanan, menyajikan, bahkan menyimpan peralatan makan. Sedangkan PKL makanan siap saji bawa pulang cenderung memiliki tempat berdagang dengan luasan yang kecil $(<3 \mathrm{~m} 2)$ karena ruang aktivitas yang dibutuhkan PKL ini hanya untuk mengolah makanan dan menyediakan tempat pembeli untuk menunggu.

3) Sebagian besar PKL (64 persen) memilih berjualan lebih dari 6 hingga 12 jam per hari. PKL yang berdagang 12-24 jam bahkan hingga lebih dari 24 jam lebih banyak dilakukan oleh PKL non makanan dan PKL jasa, hal ini disebabkan oleh jenis dagangan yang ditawarkan tidak bergantung pada waktu/ tidak cepat rusak.

4) Sebanyak 50 persen PKL di Kota Surakarta melakukan transaksi dengan pembeli selama 10 menit. Namun jika ditinjau berdasarkan jenis dagangannya, PKL makanan siap saji di bawa pulang, PKL makanan mentah, dan PKL non makanan mayoritas melakukan transaksi dengan pembeli kurang dari 10 menit. Sedangkan PKL makanan siap saji ditempat mayoritas melakukan transaksi dengan pembeli 11-20 menit, hal ini disebabkan PKL ini membutuhkan waktu ekstra untuk mengolah dan menyajikan makanan. PKL yang melakukan transaksi dengan pembeli paling lama (lebih dari 20 menit per pembeli) paling banyak dilakukan oleh PKL jasa.

5) Jumlah kunjungan pembeli/konsumen sangat mempengaruhi keuntungan yang didapat oleh para PKL. Bagi PKL dengan jenis makanan baik siap saji ditempat, dibawa pulang, maupun mentah dimana dalam mengambil keuntungan tiap barang dagangan relatif lebih sedikit, maka perlu dibedakan dengan PKL Non Makanan dan Jasa. Sejumlah 38 persen PKL mendapatkan kunjungan dari pembeli dalam jumlah sedang. 
36 persen mendapatkan kunjungan pembeli dalam jumlah minimal. Sisanya 26 persen PKL mendapatkan kunjungan pembeli dalam jumlah maksimal. PKL dengan jumlah kunjungan pembeli terbesar adalah PKL makanan siap saji dibawa pulang.

6) Sebesar 65,33 persen PKL mengaku bahwa mayoritas konsumennya berasal dari dalam Kota Surakarta. Asal konsumen ini akan berpengaruh terhadap skala operasi layanan PKL. PKL makanan siap saji dibawa pulang memiliki skala pelayanan yang lebih luas jika dibandingkan PKL jenis makanan lainnya. Sedangkan PKL makanan siap saji ditempat merupakan PKL dengan skala pelayanan yang paling kecil.

\section{b. Karakteristik Lokasi PKL}

PKL memiliki karateristik khusus dalam pemilihan lokasinya berdasarkan pertimbangan-pertimbangan tertentu. PKL akan selalu menempati ruang-ruang publik sebagai lokasi yang dianggap paling menguntungkan dan mudah dijangkau oleh konsumen (Mc.Gee dan Yeung, 1997). Meskipun selalu berada pada ruang publik, namun berdasarkan hasil studi lapangan, PKL di Kota Surakarta dalam pemilihan lokasinya dapat dibedakan berdasarkan hal-hal sebagai berikut:

1) Jenis aktivitas utama yang didekati Aktivitas utama yang didekati oleh PKL sekaligus merupakan keunggulan dan kestrategisan lokasi. Sebesar 56\% PKL mendekati fungsi perdagangan dan kegiatan jasa (perbankan dan hotel), 19,33\% PKL mendekati fungsi pendidikan, $16 \%$ PKL mendekati fungsi perkantoran, 6\% PKL mendekati fungsi rekreasi, sisanya $2,67 \%$ mendekati fungsi kesehatan. Jika ditinjau berdasarkan jenis dagangannya, PKL yang dominan dekat dengan fungsi perdagangan adalah PKL makanan mentah. Sedangkan PKL yang mendekati fungsi perkantoran didominasi oleh PKL makanan siap saji tempat. PKL makanan siap saji bawa pulang merupakan PKL yang paling banyak mendekati fungsi pendidikan dan rekreasi.

2) Jenis Pengelompokkan

Sebesar 25,33 persen PKL yang memilih dengan berkelompok dengan jenis dagangan sejenis, 36 persen PKL bercampur dengan jenis dagangan yang berbeda, 10 persen PKL tidak tergantung pada pengelompokan pada jenis dagangan PKL lainnya/fleksibel dam 32 persen PKL memilih tidak mengelompok dengan PKL lainnya. PKL makanan mentah lebih memilih berkelompok sejenis atau fleksibel dalam pengelompokkan. Sedangkan PKL jasa sebagian besar memilih bercampur dengan PKL jenis dagangan lainnya dalam pengelompokkan.

3) Sifat Pelayanan

Dalam melakukan usaha dagangnya tidak semua PKL menetap pada suatu tempat dari awal hingga akhir. Sebesar 86,67 persen PKL memilih untuk melakukan usahanya secara menetap pada suatu lokasi. PKL yang memilih menetap sementara kemudain berpindah kebanyakan dilakukan oleh PKL makanan mentah.

4) Ketergantungan Lokasi dengan Konsumen

Sebanyak 72\% PKL menganggap kedekatan dengan konsumen merupakan sesuatu yang penting dalam penentuan lokasi berdagang. PKL yang menganggap kedekatan dengan konsumen bukan menjadi hal yang terlalu penting untuk dipertimbangkan dalam memilih lokasi berdagang didominasi oleh 
PKL dengan jenis dagangan makanan mentah. Hal ini biasanya diungkapkan oleh PKL yang sudah mendapatkan pelanggan tetap sehingga dimana pun PKL tersebut berlokasi, maka pelanggannya akan selalu datang jika membutuhkan barang yang dijajakannya

\section{c. Hubungan karakteristik aktivitas dan Karakter Lokasi PKL}

Menurut Mc. Gee and Yeung (1997), PKL akan selalu menempati ruang publik sebagai lokasi yang paling menguntungkan, tempat-tempat yang mudah dijangkau oleh konsumen. Sedangkan, (Chapin dalam Haryanti, 2008) mengungkapkan bahwa karakter berlokasi tidak hanya melekat pada tapak dan relativitas posisi lahan dalam tata ruang kota saja namun juga pada struktur pembangunan manusia dan nilai sosial. Aspek manusia dan karakter dari aktivitas yang dilakukannya akan mempengaruhi keputusan dalam menentukan lokasi berdagang, yang dalam penelitian ini aspek tersebut akan didekati dengan karakter aktivitas PKL sebagai pengambil keputusan berlokasi. Pada pembahasan berikut akan dilihat hubungan antara karakteristik aktivitas PKL yang dalam hal ini akan dilihat dari 6 variabel, yaitu luas tempat berdagang, jenis sarana dagang, lama berjualan dalam sehari, lama transaksi, jumlah konsumen, dan asal konsumen.

Tabel 5.1 Hubungan Karakter Aktivitas dengan Karakter Berlokasi PKL di Kota Surakarta

\begin{tabular}{|c|c|c|c|c|}
\hline \multirow[b]{2}{*}{$\begin{array}{l}\text { Karakterist } \\
\text { ik Aktivitas }\end{array}$} & \multicolumn{4}{|c|}{ Karakter Lokasi } \\
\hline & Jenis Aktivitas & $\begin{array}{c}\text { Pengelompok- } \\
\text { kan Usaha }\end{array}$ & Sifat Layanan & $\begin{array}{l}\text { Kedekatan } \\
\text { dengan } \\
\text { Konsumen }\end{array}$ \\
\hline $\begin{array}{l}\text { Jenis Sarana } \\
\text { Dagang }\end{array}$ & $\begin{array}{l}\text { Ada hubungan } \\
\text { (Approx. Sig. : } \\
0,000 \text { ). } \\
\text { Keeratan } \\
\text { hubungan kuat } \\
\text { (Nilai } \\
\text { Coefficient } \\
\text { Contingency: } \\
0,625 \text { ) }\end{array}$ & $\begin{array}{l}\text { Tidak Ada } \\
\text { hubungan. } \\
\text { (Approx. Sig. : } \\
0,280 \text { ) }\end{array}$ & $\begin{array}{l}\text { Ada hubungan } \\
\text { (Approx. Sig. : } \\
0,000 \text { ). Keeratan } \\
\text { hubungan kuat } \\
\text { (Nilai Coefficient } \\
\text { Contingency: } \\
0,505 \text { ) }\end{array}$ & $\begin{array}{l}\text { Tidak Ada } \\
\text { hubungan. } \\
\text { (Approx. Sig. : } \\
0,631 \text { ) }\end{array}$ \\
\hline $\begin{array}{l}\text { Luas } \\
\text { Tempat } \\
\text { Berdagang }\end{array}$ & $\begin{array}{l}\text { Tidak Ada } \\
\text { hubungan. } \\
\text { (Approx. Sig. : } \\
0,232 \text { ) }\end{array}$ & $\begin{array}{l}\text { Ada hubungan } \\
\text { (Approx. Sig. : } \\
0,042 \text { ). } \\
\text { Keeratan } \\
\text { hubungan } \\
\text { lemah (Nilai } \\
\text { Coefficient } \\
\text { Contingency: } \\
0,283 \text { ) }\end{array}$ & $\begin{array}{l}\text { Ada hubungan } \\
\text { (Approx. Sig. : } \\
0,007 \text { ). Keeratan } \\
\text { hubungan lemah } \\
\text { (Nilai } \\
\text { Coefficient } \\
\text { Contingency: } \\
0,251 \text { ) }\end{array}$ & $\begin{array}{l}\text { Tidak Ada } \\
\text { hubungan. } \\
\text { (Approx. Sig. : } \\
0,055 \text { ) }\end{array}$ \\
\hline $\begin{array}{l}\text { Lama } \\
\text { Berjualan } \\
\text { Per Hari }\end{array}$ & $\begin{array}{l}\text { Tidak Ada } \\
\text { hubungan. } \\
\text { (Approx. Sig. : } \\
0,171 \text { ) }\end{array}$ & $\begin{array}{l}\text { Tidak Ada } \\
\text { hubungan. } \\
\text { (Approx. Sig. : } \\
0,134 \text { ) }\end{array}$ & $\begin{array}{l}\text { Tidak Ada } \\
\text { hubungan. } \\
\text { (Approx. Sig. : } \\
0,217 \text { ) }\end{array}$ & $\begin{array}{l}\text { Tidak Ada } \\
\text { hubungan. } \\
\text { (Approx. Sig. : } \\
0,688 \text { ) }\end{array}$ \\
\hline
\end{tabular}




\begin{tabular}{|c|c|c|c|c|}
\hline \multirow[b]{2}{*}{$\begin{array}{l}\text { Karakterist } \\
\text { ik Aktivitas }\end{array}$} & \multicolumn{4}{|c|}{ Karakter Lokasi } \\
\hline & Jenis Aktivitas & $\begin{array}{c}\text { Pengelompok- } \\
\text { kan Usaha }\end{array}$ & Sifat Layanan & $\begin{array}{l}\text { Kedekatan } \\
\text { dengan } \\
\text { Konsumen }\end{array}$ \\
\hline $\begin{array}{l}\text { Lama } \\
\text { Transaksi }\end{array}$ & $\begin{array}{l}\text { Tidak Ada } \\
\text { hubungan. } \\
\text { (Approx. Sig. : } \\
0,832 \text { ) }\end{array}$ & $\begin{array}{l}\text { Ada hubungan } \\
\text { (Approx. Sig. : } \\
0,041 \text { ). } \\
\text { Keeratan } \\
\text { hubungan } \\
\text { lemah (Nilai } \\
\text { Coefficient } \\
\text { Contingency: } \\
0,284 \text { ) }\end{array}$ & $\begin{array}{l}\text { Tidak Ada } \\
\text { hubungan. } \\
\text { (Approx. Sig. : } \\
0,288 \text { ) }\end{array}$ & $\begin{array}{l}\text { Tidak Ada } \\
\text { hubungan. } \\
\text { (Approx. Sig. : } \\
0,412 \text { ) }\end{array}$ \\
\hline $\begin{array}{l}\text { Jumlah } \\
\text { Pembeli }\end{array}$ & $\begin{array}{l}\text { Ada hubungan } \\
\text { (Approx. Sig. : } \\
0,000 \text { ). } \\
\text { Keeratan } \\
\text { hubungan kuat } \\
\text { (Nilai } \\
\text { Coefficient } \\
\text { Contingency: } \\
0,408 \text { ) }\end{array}$ & $\begin{array}{l}\text { Tidak Ada } \\
\text { hubungan. } \\
\text { (Approx. Sig. : } \\
0,138 \text { ) }\end{array}$ & $\begin{array}{l}\text { Ada hubungan } \\
\text { (Approx. Sig. : } \\
0,133 \text { ) }\end{array}$ & $\begin{array}{l}\text { Ada hubungan } \\
\text { (Approx. Sig. : } \\
0,050 \text { ). } \\
\text { Keeratan } \\
\text { hubungan } \\
\text { lemah (Nilai } \\
\text { Coefficient } \\
\text { Contingency: } \\
0,196)\end{array}$ \\
\hline $\begin{array}{l}\text { Asal } \\
\text { Konsumen }\end{array}$ & $\begin{array}{l}\text { Ada hubungan } \\
\text { (Approx. Sig. : } \\
0,009 \text { ). } \\
\text { Keeratan } \\
\text { hubungan kuat } \\
\text { (Nilai } \\
\text { Coefficient } \\
\text { Contingency: } \\
0,345 \text { ) }\end{array}$ & $\begin{array}{l}\text { Tidak Ada } \\
\text { hubungan. } \\
\text { (Approx. Sig. : } \\
0,423 \text { ) }\end{array}$ & $\begin{array}{l}\text { Ada hubungan } \\
\text { (Approx. Sig. : } \\
\text { 0,049). Keeratan } \\
\text { hubungan sangat } \\
\text { lemah (Nilai } \\
\text { Coefficient } \\
\text { Contingency:0,1 } \\
\text { 97) }\end{array}$ & $\begin{array}{l}\text { Tidak Ada } \\
\text { hubungan. } \\
\text { (Approx. Sig. : } \\
0,177 \text { ) }\end{array}$ \\
\hline
\end{tabular}

Berdasarkan tabel di atas, maka dapat dijelaskan hubungan antara karakter aktivitas dengan karakter berlokasi PKL di Kota Surakarta:

1) Secara umum, aktivitas utama yang didekati PKL memiliki hubungan dengan jenis sarana dagang, jumlah pembeli, dan asal konsumen. Besarnya koefisien yang ada menunjukkan keeratan hubungan yang terbentuk antar kedua variabel. Keeratan hubungan paling besar dengan jenis aktivitas utama yang didekati PKL adalah variabel jenis sarana dagang yang digunakan dengan koefisien kontingensi $(0,625)$, sedangkan keeratan hubungan paling kecil yang dibentuk dengan jenis aktivitas utama yang didekati adalah variabel asal konsumen (0,345). Meskipun sebagian besar PKL mendekati fungsi perdagangan, PKL makanan siap saji dibawa pulang yang mendekati fungsi pendidikan dan rekreasi mayoritas menggunakan jenis sarana dagang berupa gerobak dan jumlah pembelinya relatif banyak. PKL yang mendekati fungsi rekreasi juga biasanya memiliki skala pelayanan yang lebih besar dimana asal konsumennya bisa dari luar kota. Sedangkan, PKL yang mendekati 
fungsi perkantoran mayoritas dilakukan oleh PKL makanan siap saji ditempat dimana sebagian besar konsumen di sekitar fungsi perkantoran tersebut.

2) Variabel pola pengelompokkan memiliki hubungan dengan variable luas tempat dagang dan lama transaksi. Hubungan paling erat dengan variable pola pengelompokkan dibentuk oleh variable luas tempat dagang (koefisien kontingensi:0,283). Secara keseluruhan hubungan yang dibentuk antar variabel aktivitas PKL dengan variabel jenis pengelompokkan PKL ini lebih kecil jika dibandingkan dengan hubungan yang dibentuk antara variabel aktivitas PKL dengan jenis aktivitas utama yang didekati PKL. PKL yang cenderung berkelompok dengan PKL sejenis mayoritas dilakukan oleh PKL makanan mentah dan makanan siap saji ditempat. PKL yang cenderung berkelompok campur dengan PKL jenis lainnya mayoritas dilakukan oleh PKL jasa dan PKL non makanan. PKL yang fleksibel dengan pengelompokkan mayoritas dilakukan pula oleh PKL makanan mentah dan jasa. PKL yang tidak mengelompok mayoritas dilakukan oleh PKL makanan mentah dan jasa. PKL yang memilih untuk berkelompok biasanya memiliki peraturan yang disepakati antar kelompoknya, termasuk terkait dengan sarana dagangnya. Sedangkan, PKL yang memilih tidak mengelompok lebih bebas dalam menentukan sarana dagangnya.

3) Dalam melakukan usaha dagangnya tidak semua PKL menetap pada suatu tempat dari awal hingga akhir. Berdasarkan hasil analisis, variabel sifat layanan PKL memiliki hubungan dengan variabel jenis sarana dagang, luas tempat berdagang, dan asal menggunakan sarana dagang warung/tenda dimana konsumennya bisa saja hanya bergantung pada konsumen. Hubungan yang paling erat dibentuk oleh variabel jenis sarana dagang. PKL makanan siap saji ditempat yang lebih banyak menggunakan sarana dagang warung/ tenda mayoritas berdagang secara menetap. Hal ini terjadi karena PKL makanan siap saji ditempat dengan sarana dagang warung/tenda membutuhkan waktu ekstra jika harus berpindah karena akan membongkar dan menyusun tendanya kembali. Sedangkan PKL dengan jenis makanan siap saji diibawa pulang yang cenderung menggunakan sarana dagang gerobak akan lebih sering menetap sementara kemudian berpindah lagi.

4) Sebagian besar PKL menganggap kedekatan dengan konsumen merupakan sesuatu yang penting dalam penentuan lokasi berdagang. Berdasarkan hasil analisis, variabel kedekatan dengan konsumen hanya memiliki hubungan dengan variabel jumlah pembeli dengan tingkat keeratan hubungan yang lemah. PKL yang cenderung mendekati konsumen bisa jadi mendapatkan jumlah konsumen yang cukup banyak, namun karena mendekati konsumen dapat membuat skala pelayanannya menjadi tidak terlalu luas, karena konsumen yang berkunjung berasal dari sekitar lokasi berdagang PKL. Sedangkan kondisi sebalikanya terjadi dimana PKL yang menganggap kedekatan konsumen tidak penting berpeluang besar dalam meluaskan skala pelayanannya, dimana konsumen yang datang tidak hanya dari konsumen yang didekati atau sekitar lokasi PKL.

\section{KESIMPULAN}

Adanya perbedaan persepsi di antara 
PKL dalam berlokasi yang dianggap mendukung keberhasilan aktivitas usahanya, pada akhirnya membuat karakteriktik aktivitas yang dilakukan PKL secara langsung maupun tidak langsung mempengaruhi keputusan PKL dalam berlokasi. Hubungan antara karakteristik berlokasi dan karakteristik aktivitasnya tersebut, dapat dilihat dari:

a. aktivitas utama yang didekati dengan jenis sarana dagang, jumlah konsumen, dan asal konsumen

b. sifat pelayanan dengan luas tempat berdagang dan lama transaksi

c. pengelompokan usaha dengan jenis sarana dagang, luas tempat berdagang, dan asal konsumen

d. kedekatan konsumen dengan jumlah konsumen.

Hanya variabel lama waktu berdagang yang tidak memiliki hubungan apapun dengan karakteristik berlokasi PKL. Sedangkan jika ditinjau berdasarkan jenis dagangannya, dapat disimpulkan sebagai berikut:

a. PKL makanan siap saji ditempat cenderung menggunakan sarana dagang warung/ tenda yang membutuhkan luas tempat berdagang yang lebih besar (3$6 \mathrm{~m}^{2}$ bahkan lebih dari $6 \mathrm{~m}^{2}$ ), melakukan transaksi dengan konsumen dalam waktu sedang, dan mendapatkan jumlah konsumen sedang, serta mayoritas konsumennya berasal dari sekitar lokasi berdagang. Aktivitas tersebut kemudian membuat PKL makanan siap saji ditempat cenderung memilih berlokasi mendekati fungsi perdagangan dan perkantoran, cenderung memilih mengelompok dalam berlokasi, memiliki sifat layanan yang menetap serta menganggap faktor kedekatan konsumen merupakan hal penting.

b. PKL makanan siap saji dibawa pulang cenderung menggunakan sarana dagang gerobak/kereta yang membutuhkan luas tempat berdagang yang relative kecil (< $3 \mathrm{~m} 2$ ), melakukan transaksi dengan konsumen dalam waktu yang cukup singkat, mendapatkan konsumen dalam jumlah maksimal dan memiliki skala pelayanan yang paling luas. Hal tersebut memiliki hubungan dengan karakter penentuan lokasi PKL makanan siap saji dibawa pulang dimana cenderung mendekati fungsi perdagangan, pendidikan, dan rekreasi, cenderung mengelompok, memiliki sifat layanan yang sebagian besar menetap namun terdapat beberapa yang memilih menetap sementara kemudian berpindah, dan menganggap faktor kedekatan dengan konsumen merupakan hal yang penting.

c. PKL makanan mentah cenderung menggunakan sarana dagang alas/ gelaran yang mempengaruhi luasan dagang yang dibutuhkan (kurang dari $3 m^{2}$ dan 3-6m²), melakukan transaksi dengan konsumen dalam waktu yang cukup singkat, memiliki skala pelayanan yang tidak terlalu luas, dan mendapatkan jumlah konsumen minimal. Hal ini berhubungan dengan alasan pemilihan lokasi PKL ini yang cenderung mendekati fungsi perdagangan, cenderung fleksibel dalam pengelompokkan, memiliki sifat layanan yang sebagian menetap dan sebagian lagi menetap sementara kemudian berpindah, serta cenderung menganggap faktor kedekatan dengan konsumen merupakan hal yang tidak terlalu penting.

d. PKL non makanan cenderung menggunakan sarana dagang gerobak dan alas yang membutuhkan luasan dagang (kurang dari $3 \mathrm{~m}^{2}$ dan $3-6 \mathrm{~m}^{2}$ ), melakukan transaksi dalam waktu yang relative singkat, mendapatkan konsumen dalam jumlah sedang, dan memiliki skala pelayanan yang tidak terlalu luas. Aktivitas tersebut memiliki hubungan dengan karakter berlokasinya, dimana cenderung mendekati fungsi perdagangan, pendidikan, dan perkantoran, cenderung lebih memilih untuk tidak mengelompok ataupun jika mengelompok memilih campur dengan PKL jenis dagangan lainnya, memiliki sifat layanan cenderung menetap, dan 
ketergantungan lokasi dengan konsumen dianggap penting.

e. PKL jasa cenderung menggunakan sarana dagang warung/tenda untuk melindungi peralatan jasanya, memiliki waktu transaksi yang relative lama dengan konsumen, mendapatkan konsumen dalam jumlah sedang, dan memiliki skala pelayanan yang tidak luas. Hal terebut berhubungan dengan karakter berlokasi PKL ini dimana cenderung mendekati fungsi perdagangan yang sangat bergantung pada fungsi tersebut untuk mendapatkan konsumen, cenderung berkelompok/bercampur dengan jenis dagangan lain karena lama transaksi yang dibutuhkan 'menuntut' konsumen untuk mengisi waktunya dengan berinteraksi dengan PKL jenis dagangan lain.

\section{DAFTAR PUSTAKA}

Haryanti, D. 2008. Kajian Pola

Pemnafaatan Ruang terbuka Publik

Kawasan Bundaran Simpang Lima.

Magister Teknik Perencanaan

Wilayah dan Kota UNDIP, Semarang

Mc. Gee, T. G dan Yeung, Y. M. 1977.

Hawkers In Southeast Asian Cities: Planning for The Bazaar

Economiy. Canada: International Development Research Centre.

Rahayu, et al. 2007. Studi Penataan

Pedagang Kaki Lima di Kabupaten

Sukoharjo. UNS Surakarta

Rahayu, et al. 2012. Strategi

Pemberdayaan PKL secara

Partisipatif dalam Mendorong

Ekonomi yang Berkelanjutan di

Kota Surakarta. UNS, Surakarta

Rahayu, et al. 2013. Strategi

Pemberdayaan PKL secara

Partisipatif dalam Mendorong

Ekonomi yang Berkelanjutan di

Kota Surakarta. UNS, Surakarta
Rahayu, et al. 2014. Model Zonasi Lokasi PKL yang Berkelanjutan dalam Mendukung Pengentasan

Kemiskinan di Kota Surakarta.

UNS, Surakarta

Swasono, S ed. 1987. Sistem Ekonomi dan Demokrasi Ekonomi : Membangun Sistem Ekonomi Nasional. Jakarta : Universitas Indonesia Press 
